\title{
Association Between the Interferon- $\gamma+874$ T/A Polymorphism and the Risk and Clinical Manifestations of Systemic Lupus Erythematosus: A Preliminary Study
}

\author{
Shanshan Liu (DD \\ Ju Li \\ Yongsheng Li \\ Yan Liu \\ Kai Wang \\ Wenyou Pan
}

Department of Rheumatology, The Affiliated Huaian No.I People's Hospital of Nanjing Medical University, Huaian, People's Republic of China
Correspondence: Shanshan Liu Department of Rheumatology, The Affiliated Huaian No.I People's Hospital of Nanjing Medical University, Huaian, People's Republic of China

Email drshanshanliu@I63.com
Background: Interferon-gamma (IFN- $\gamma$ ) is a pivotal cytokine involved in the development of systemic lupus erythematosus (SLE). The IFN- $\gamma+874$ T/A polymorphism has been shown to be related to the susceptibility to SLE in other races, but this has not been investigated in the Chinese Han population.

Methods: We designed this study to interpret the potential correlation between this polymorphism and SLE risk in a Chinese Han population. We included 374 SLE patients and 405 controls in this study. Odds ratios and relevant $95 \%$ confidence intervals were figured out to evaluate the potential strength of the association.

Results: Data revealed that the IFN- $\gamma+874$ T/A polymorphism showed an association with an enhanced risk of SLE in this Chinese Han population. TA or TA +AA genotype carriers showed an increased risk of developing SLE. Subgroup analyses found that this polymorphism elevated the risk of SLE among females. Additionally, this polymorphism was associated with clinical manifestations of SLE including lupus nephritis, proteinuria, anti-dsDNA antibodies, anti-Sm antibodies, and SLICC/ACR damage index. Furthermore, we conducted a meta-analysis and found that this polymorphism was associated with the risk of SLE, especially among Asians.

Conclusion: Totally, this study detects that the IFN $-\gamma+874 \mathrm{~T} / \mathrm{A}$ polymorphism is related to the risk and clinical manifestations of SLE in a Chinese Han population.

Keywords: interferon-gamma, systemic lupus erythematosus, case-control study, +874 T/A polymorphism

\section{Introduction}

Systemic lupus erythematosus (SLE), a chronic autoimmune disorder, is characterized by abnormalities of the immune system, autoantibodies production, multiple types of tissue damage, and other clinical symptoms. ${ }^{1}$ Immune characteristics of SLE include loss of immunological self-tolerance, and enhanced $\mathrm{T}$ and $\mathrm{B}$ cell responses. ${ }^{2}$ The prevalence of SLE ranges from 20 to 150 cases per 100,000 individuals, and appears to be increasing. ${ }^{3}$ The pathogenesis of this disorder has not yet been fully elucidated. Numerous studies have demonstrated that genetic and environmental factors, and immune abnormalities are associated with the pathogenesis of SLE, ${ }^{4-8}$ and have uncovered multiple loci related to SLE risk. ${ }^{9-13}$

Interferon-gamma (IFN- $\gamma$ ) is a pivotal cytokine, which correlated with the development of autoimmune diseases. ${ }^{14}$ IFN- $\gamma$ is primarily produced by immune 
cells such as $\mathrm{T}$ and NK cells. IFN- $\gamma$ is involved in both acquired and innate immunity, ${ }^{15}$ and regulates immune responses such as antigen presentation and phagocytosis. The IFN- $\gamma$ signaling pathway is activated in SLE patients. $^{16}$ Thomason et al showed that IFN- $\gamma$ activation could indicate the disease activity of SLE patients. ${ }^{17}$ In addition, the response to ustekinumab treatment in SLE patients was related to the suppression of serum IFN- $\gamma$ levels. ${ }^{18}$ Furthermore, IFN- $\gamma$ was reported to be related to the cerebral atrophy in SLE patients. ${ }^{19}$ Kokic et al demonstrated that the median values of IFN- $\gamma$ were significantly elevated in patients with SLE than those in controls. $^{20}$

The IFN- $\gamma$ gene is shown to be located on chromosome 12q24. A single-nucleotide polymorphism (SNP) was located at position +874 in the first intron of the IFN- $\gamma$ gene, which was related to its production level. ${ }^{21}$ Several studies have explored the potential link between the +874 T/A polymorphism in IFN- $\gamma$ gene and SLE risk. ${ }^{22-28}$ However, no Chinese studies have been undertaken to address this issue. In this case-control study, we aimed to interpret the relationship between this polymorphism and SLE risk and disease features in a Chinese Han population. In addition, we performed a meta-analysis to interpret the potential correlation between this locus and SLE risk.

\section{Patients and Methods Subjects}

This study included 374 SLE cases and 405 controls from Huaian No.1 People's Hospital. SLE patients were diagnosed according to the 1997 American College of Rheumatology (ACR) criteria. $^{29}$ The average age of SLE patients was $34.42 \pm 9.01$ years. The inclusion criteria for SLE patients were patients receiving first treatment, and patients who met the revised SLE classification criteria of the ACR. Patients were excluded as follows: (1) subjects with autoimmune diseases; (2) patients had a family history of SLE; (3) patients received treatment for SLE; (4) patients did not provide informed consent. The group of 405 controls were ethnically matched individuals including 40 males and 365 females, with an average age of $34.36 \pm 8.65$ years. These controls were sex- and age-matched to the SLE patients. Controls were excluded as follows: individuals with a history of SLE; controls with inflammatory or autoimmune diseases; subjects with a history of cancer. The controls were individuals receiving a physical examination in the same hospital. The lupus nephritis diagnosis was based on biopsy. All participants provided relevant written informed consent. This study was approved by the institutional review board of our hospital (Huaian No.1 People's Hospital), which conformed to the Declaration of Helsinki.

\section{DNA Extraction and Genotyping}

Peripheral blood was collected from all participants. Genomic DNA samples were extracted by use of TIANamp Blood DNA kits (TIANGEN, Beijing, China). The IFN- $\gamma$ gene was screened by the NCBI dbSNP database and SNPinfo (http:// snpinfo.niehs.nih.gov/snpfunc.htm) to selected functional polymorphisms. The SNP was analyzed using a custom-bydesign 48-Plex single nucleotide polymorphism scan ${ }^{\mathrm{TM}} \mathrm{Kit}$. The extracted genomic DNA sample was genotyped by a double ligation and multiplex fluorescence polymerase chain reaction (PCR) as previously described. ${ }^{30,31}$ Eight percent of the samples were genotyped with second time. The concordance rate of the repeated samples was $100 \%$.

\section{Statistical Analyses}

Data were mainly analyzed by SPSS 22.0 software (SPSS Inc., Chicago, USA). All characteristics were displayed as frequency (percentage) or mean \pm standard deviation. Categorical variables were analyzed by the Chi-square $\left(\chi^{2}\right)$ test, and continuous variables by the Student's $t$-test, and a goodness-of-fit $\chi^{2}$ test was utilized for assessing the Hardy-Weinberg equilibrium (HWE). Logistic regression analysis was used for calculating relevant odds ratios (ORs) and 95\% confidence intervals (CIs); the results of different genetic models were calculated after adjustment for body mass index (BMI), age, and gender. A metaanalysis was designed to address the correlation between the polymorphism and SLE risk. Significant differences were considered when the $P$-value was $<0.05$.

\section{Results}

\section{Study Population}

A total of 374 SLE patients (36 males and 338 females) and 405 controls (40 males and 365 females) were included in this study. Variables for the subjects are shown in Table 1. The ages of the cases and controls were $34.42 \pm 9.01$ years and $34.36 \pm 8.65$ years, respectively. SLE cases and controls were matched for age, BMI, and gender. Clinical indexes of SLE patients are summarized in Table 1. 
Table I Patient Demographics and Risk Factors in SLE Patients and Controls

\begin{tabular}{|c|c|c|c|}
\hline Variables & SLE Cases & Controls & $P$-value \\
\hline Number of subjects & 374 & 405 & \\
\hline Age (years), Mean \pm SD & $34.42 \pm 9.01$ & $34.36 \pm 8.65$ & 0.923 \\
\hline \multicolumn{4}{|l|}{ Gender } \\
\hline Male & $36(9.63 \%)$ & $40(9.88 \%)$ & 0.906 \\
\hline Female & $338(90.37 \%)$ & $365(90.12 \%)$ & \\
\hline BMI & $24.02 \pm 2.93$ & $24.06 \pm 3.04$ & 0.863 \\
\hline Age at disease onset, Mean \pm SD & $29.48 \pm 7.62$ & & \\
\hline SLEDAI, Median (Range) & $12(2-3 \mid)$ & & \\
\hline SLICC/ACR damage index scores, Median (Range) & $0(0-6)$ & & \\
\hline Rash (N (\%)) & $97(25.94 \%)$ & & \\
\hline Photosensitivity (N (\%)) & $149(39.84 \%)$ & & \\
\hline Mucosal ulcers (N (\%)) & III (29.68\%) & & \\
\hline Arthritis (N (\%)) & $98(26.20 \%)$ & & \\
\hline Pleuritis (N (\%)) & II4(30.48\%) & & \\
\hline Pericarditis (N (\%)) & $105(28.07 \%)$ & & \\
\hline Lupus nephritis (N (\%)) & $254(67.91 \%)$ & & \\
\hline Proteinuria (N (\%)) & $235(62.83 \%)$ & & \\
\hline Psychosis (N (\%)) & $29(7.75 \%)$ & & \\
\hline Haemolytic anaemia (N (\%)) & $119(31.82 \%)$ & & \\
\hline Anti-nucleosome Ab (N (\%)) & $132(35.29 \%)$ & & \\
\hline ANA (N (\%)) & 359 (95.99\%) & & \\
\hline Anti-dsDNA Ab (N (\%)) & $243(64.97 \%)$ & & \\
\hline Anti-Smith Ab (N (\%)) & $92(24.60 \%)$ & & \\
\hline Anti-Ro/SSA Ab (N (\%)) & 115 (30.75\%) & & \\
\hline Anti-La/SSB Ab (N (\%)) & $62(16.58 \%)$ & & \\
\hline Anti-RNP Ab (N (\%)) & 150 (40.1 I\%) & & \\
\hline
\end{tabular}

Abbreviations: N, number; SLE, systemic lupus erythematosus; Ab, antibodies; dsDNA, double-stranded DNA; RNP, ribonucleoprotein; ANA, anti-nuclear antibodies; SLEDAI, systemic lupus erythematosus disease activity index; SD, standard deviation.

Association Between the IFN- $\gamma+874$ T/A Polymorphism and SLE Risk

The genotype and allele distributions of two groups are listed in Table 2. The distribution of this polymorphism in controls was in line with the HWE test $(P=0.965)$. Data revealed that patients with the TA or TA +AA genotype showed an enhanced risk of SLE (TA vs TT, OR, 1.45; 95\% CI, 1.05-1.99; $P=0.023)$. Even after adjusting for age, BMI, and gender, the $+874 \mathrm{~T} / \mathrm{A}$ polymorphism of the IFN- $\gamma$ gene still elevated the risk of SLE. In addition, subgroup analyses of gender, BMI, and age were performed (Table 3). This study found that the $+874 \mathrm{~T} / \mathrm{A}$ polymorphism enhanced the risk of SLE among females.

Additionally, we conducted a meta-analysis to emphasize the correlation between this polymorphism and SLE risk by searching the databases of PubMed, Embase, and 
Table 2 Correlations Between the IFN- $\gamma+874$ T/A Polymorphism and the Risk of Systemic Lupus Erythematosus

\begin{tabular}{|c|c|c|c|c|c|c|}
\hline Genotype/Allele & Case (N, \%) & Control (N, \%) & OR, (95\% Cl) & $P$-value & $*$ OR, $(95 \% \mathrm{Cl})$ & *P-value \\
\hline TT & $247(66.0 \%)$ & $30 I(74.3 \%)$ & 1.00 & - & 1.00 & - \\
\hline TA & $114(30.5 \%)$ & $96(23.7 \%)$ & $1.45,(1.05-1.99)$ & 0.023 & $1.45,(1.05-1.99)$ & 0.024 \\
\hline AA & $13(3.5 \%)$ & $8(2.0 \%)$ & $1.98,(0.81-4.85)$ & 0.135 & $1.98,(0.81-4.87)$ & 0.136 \\
\hline TT & $247(66.0 \%)$ & $30 I(74.3 \%)$ & 1.00 & - & 1.00 & - \\
\hline $\mathrm{TA}+\mathrm{AA}$ & $127(34.0 \%)$ & $104(25.7 \%)$ & $1.49,(1.09-2.03)$ & 0.012 & $1.49,(1.09-2.03)$ & 0.012 \\
\hline $\mathrm{TA}+\mathrm{TT}$ & $36 \mid(96.5 \%)$ & $397(98.0 \%)$ & 1.00 & - & 1.00 & - \\
\hline AA & $13(3.5 \%)$ & $8(2.0 \%)$ & I.79, (0.73-4.36) & 0.202 & $1.79,(0.73-4.38)$ & 0.201 \\
\hline $\mathrm{T}$ & $608(81.3 \%)$ & $698(86.2 \%)$ & 1.00 & - & - & - \\
\hline A & $140(\mid 8.7 \%)$ & $112(13.8 \%)$ & $1.44,(1.09-1.88)$ & 0.009 & - & - \\
\hline
\end{tabular}

Notes: *Adjustment for age, body mass index, and gender. Bold values are statistically significant $(P<0.05)$.

Abbreviation: $\mathrm{N}$, number.

Table 3 Stratified Analyses Between the IFN- $\gamma+874$ T/A Polymorphism and the Risk of Systemic Lupus Erythematosus

\begin{tabular}{|c|c|c|c|c|}
\hline \multirow[t]{2}{*}{ Variables } & Model I & Model 2 & Model 3 & Model 4 \\
\hline & OR (95\% CI); P & OR (95\% CI); P & OR (95\% CI); P & OR (95\% Cl); P \\
\hline \multicolumn{5}{|l|}{ Age (years) } \\
\hline$<40$ & $1.39(0.94-2.04) ; 0.097$ & $2.26(0.74-6.86) ; 0.14 \mathrm{I}$ & $2.07(0.69-6.27) ; 0.188$ & $1.45(1.00-2.10) ; 0.052$ \\
\hline$\geq 40$ & $1.56(0.87-2.77) ; 0.131$ & $1.50(0.33-6.96) ; 0.889$ & $1.31(0.29-5.99) ; 1.000$ & $1.55(0.89-2.71) ; 0.121$ \\
\hline \multicolumn{5}{|l|}{ BMI } \\
\hline$<25$ & $1.38(0.92-2.07) ; 0.118$ & $2.10(0.69-6.40) ; 0.183$ & $1.92(0.63-5.8 I) ; 0.24 I$ & I.44(0.97-2.12); 0.069 \\
\hline$\geq 25$ & $1.56(0.93-2.63) ; 0.092$ & I.74(0.38-7.99); 0.736 & I.54(0.34-7.0I); 0.856 & $1.58(0.95-2.61) ; 0.076$ \\
\hline \multicolumn{5}{|l|}{ Gender } \\
\hline Male & $0.68(0.22-2.03) ; 0.483$ & $0.32(0.03-3.28) ; 0.629$ & $0.35(0.04-3.55) ; 0.685$ & $0.59(0.2 \mathrm{I}-\mathrm{I} .66) ; 0.317$ \\
\hline Female & I.56(I.II-2.18); 0.009 & $3.00(1.04-8.65) ; 0.033$ & $2.65(0.92-7.60) ; 0.060$ & I.64(I.18-2.27); 0.003 \\
\hline
\end{tabular}

Notes: Model I, TA vs TT; Model 2, AA vs TT; Model 3, AA vs TA+TT; Model 4, AA+TA vs TT; Bold values are statistically significant ( $P<0.05)$.

Abbreviation: BMI, body mass index.

Wanfang. Results indicated that TA, AA, or TA+AA genotypes increased the risk of SLE (Supplementary Table 1). Besides, this meta-analysis suggested that A allele could also enhance the risk of SLE (A vs T, OR, 1.21; 95\% CI, 1.09-1.34; $P=0.001)$. Subgroup analysis was conducted for ethnicity (Supplementary Table 2). We found that the $+874 \mathrm{~T} / \mathrm{A}$ polymorphism was linked with an elevated risk of SLE among Asians.

\section{The IFN- $\gamma+874$ T/A Polymorphism and Clinical Manifestations of SLE}

Clinical manifestations of SLE and their associations with the +874 T/A polymorphism were explored (Table 4). Data indicated that this polymorphism showed an association with the clinical manifestations of SLE including lupus nephritis, proteinuria, anti-Sm antibodies (Ab), antidsDNA Ab, and SLICC/ACR Damage Index (SDI). However, this polymorphism was not related with malar rash, photosensitivity, discoid rash, arthritis, oral ulcers, pericarditis, pleuritis, neuropsychiatric disorder, haemolytic anaemia, anti-nucleosome $\mathrm{Ab}$, anti-nuclear antibodies (ANA), anti-La/SSB Ab, anti-Ro/SSA Ab, or anti-RNP Ab.

\section{Discussion}

In this case-control study, we found that the $+874 \mathrm{~T} / \mathrm{A}$ polymorphism was related with an elevated risk of SLE in a Chinese Han population, especially among females. Additionally, this study revealed that this polymorphism was associated with lupus nephritis, proteinuria, antidsDNA Ab, anti-Sm Ab, and SDI.

Previous studies indicated that IFN- $\gamma$ levels in the active stages of SLE were higher in patients than in controls, ${ }^{20,32-37}$ suggesting that increased levels of IFN- $\gamma$ may lead to the pathogenesis of SLE. However, two studies showed that IFN- $\gamma$ levels did not differ in SLE patients compared to controls. ${ }^{38,39}$ Further studies are 
Table 4 The Associations Between the IFN- $\gamma+874$ T/A Polymorphism and Clinical Characteristics of Systemic Lupus Erythematosus

\begin{tabular}{|c|c|c|c|c|}
\hline \multirow[t]{2}{*}{ Parameter } & \multicolumn{4}{|c|}{ Genotype Distributions } \\
\hline & TT & TA & AA & TA+AA \\
\hline $\begin{array}{l}\text { Rash (presence/absence) } \\
\text { OR ( } 95 \% \mathrm{Cl}) \\
\text { P-value }\end{array}$ & I.0 (reference) & $\begin{array}{l}\text { I.12(0.68-I.84); } \\
0.666^{\text {TAvsTT }}\end{array}$ & $\begin{array}{l}0.24(0.03-1.87) \\
0.250^{\text {AAvsTT }}\end{array}$ & $\begin{array}{l}\text { I.00(0.62-I.64); } \\
0.988^{\text {AA+TAvsTT }}\end{array}$ \\
\hline $\begin{array}{l}\text { Photosensitivity (presence/absence) } \\
\text { OR (95\% Cl); } \\
\text { P-value }\end{array}$ & I.0 (reference) & $\begin{array}{l}\text { I.05(0.67-I.65); } \\
0.845^{\text {TAvsTT }}\end{array}$ & $\begin{array}{l}\text { I.33(0.43-4.06); } \\
0.621^{\text {AAvsTT }}\end{array}$ & $\begin{array}{l}\text { I.07(0.69-I.66); } \\
0.754^{\text {AA+TAvsTT }}\end{array}$ \\
\hline $\begin{array}{l}\text { Mucosal ulcers (presence/absence) } \\
\text { OR ( } 95 \% \mathrm{Cl}) \\
\text { P-value }\end{array}$ & I.0 (reference) & $\begin{array}{l}\text { I.0I(0.62-I.65); } \\
0.958^{\text {TAvsTT }}\end{array}$ & $\begin{array}{l}\text { I.06(0.32-3.55); } \\
\text { I.000 AAvsTT }\end{array}$ & $\begin{array}{l}\text { I.02(0.64-I.63); } \\
0.94 \mathrm{I}^{\mathrm{AA}+\mathrm{TAvs} T \mathrm{~T}}\end{array}$ \\
\hline $\begin{array}{l}\text { Arthritis (presence/absence) } \\
\text { OR ( } 95 \% \mathrm{Cl}) \\
\text { P-value }\end{array}$ & I.0 (reference) & $\begin{array}{l}\text { I.44(0.88-2.35); } \\
0.145^{\text {TAvsTT }}\end{array}$ & $\begin{array}{l}0.57(0.12-2.63) \\
0.689^{\text {AAvsTT }}\end{array}$ & $\begin{array}{l}\text { I.33(0.82-2.15); } \\
0.241^{\text {AA+TAvsTT }}\end{array}$ \\
\hline $\begin{array}{l}\text { Pleuritis (presence/absence) } \\
\text { OR ( } 95 \% \mathrm{Cl}) \\
\text { P-value }\end{array}$ & I.0 (reference) & $\begin{array}{l}0.92(0.56-1.49) \\
0.726^{\text {TAvsTT }}\end{array}$ & $\begin{array}{l}\text { I.4I (0.45-4.44); } \\
0.782^{\text {AAvsTT }}\end{array}$ & $\begin{array}{l}0.96(0.60-1.53) ; \\
\left.0.866\right|^{\text {AA+TAvsTT }}\end{array}$ \\
\hline $\begin{array}{l}\text { Pericarditis (presence/absence) } \\
\text { OR (95\% Cl); } \\
\text { P-value }\end{array}$ & I.0 (reference) & $\begin{array}{l}0.91(0.55-1.49) \\
0.702^{\text {TAvsTT }}\end{array}$ & $\begin{array}{l}0.44(0.10-2.04) \\
0.449^{\text {AAvs TT }}\end{array}$ & $\begin{array}{l}0.85(0.53-1.38) \\
0.519^{\text {AA+TAvsTT }}\end{array}$ \\
\hline $\begin{array}{l}\text { Lupus nephritis (presence/absence) } \\
\text { OR ( } 95 \% \mathrm{Cl}) \\
\text { P-value }\end{array}$ & 1.0 (reference) & $\begin{array}{l}2.11(1.26-3.53) \\
0.004^{\text {TAvsTT }}\end{array}$ & $\begin{array}{l}1.98(0.53-7.37) \\
0.460^{\text {AAvsTT }}\end{array}$ & $\begin{array}{l}2.08(1.27-3.40) \\
0.003^{A A+T A v s T T}\end{array}$ \\
\hline $\begin{array}{l}\text { Proteinuria (presence/absence) } \\
\text { OR }(95 \% \mathrm{Cl}) \\
\text { P-value }\end{array}$ & I.0 (reference) & $\begin{array}{l}\text { I.73(I.07-2.78); } \\
0.024^{\text {TAvsTT }}\end{array}$ & $\begin{array}{l}\text { I.58(0.47-5.28); } \\
0.452^{\text {AAvsTT }}\end{array}$ & $\begin{array}{l}\text { I.7I(I.08-2.7I); } \\
0.021^{\text {AA+TAvsTT }}\end{array}$ \\
\hline $\begin{array}{l}\text { Psychosis (presence/absence) } \\
\text { OR ( } 95 \% \mathrm{Cl}) \\
\text { P-value }\end{array}$ & I.0 (reference) & $\begin{array}{l}0.96(0.40-2.28) \\
0.927^{\text {TAvsTT }}\end{array}$ & $\begin{array}{l}3.82(0.96-15.12) \\
0.130^{\text {AAvsTT }}\end{array}$ & $\begin{array}{l}\text { I.2I(0.55-2.64); } \\
0.638^{\text {AA+TAvsTT }}\end{array}$ \\
\hline $\begin{array}{l}\text { Haemolytic anaemia (presence/absence) } \\
\text { OR }(95 \% \mathrm{Cl}) \\
\text { P-value }\end{array}$ & I.0 (reference) & $\begin{array}{l}0.80(0.49-1.30) \\
0.368^{\text {TAvsTT }}\end{array}$ & $\begin{array}{l}\text { I.76(0.57-5.40); } \\
0.488^{\text {AAvsTT }}\end{array}$ & $\begin{array}{l}0.88(0.55-1.39) \\
0.572^{\text {AA+TAvsTT }}\end{array}$ \\
\hline $\begin{array}{l}\text { Anti-nucleosome Ab (positive/negative) } \\
\text { OR }(95 \% \mathrm{Cl}) \\
\text { P-value }\end{array}$ & I.0 (reference) & $\begin{array}{l}\text { I.09(0.69-I.73); } \\
0.709^{\text {TAvsTT }}\end{array}$ & $\begin{array}{l}0.83(0.25-2.78) \\
1.000^{\mathrm{AAvsTT}}\end{array}$ & $\begin{array}{l}\text { I.48(0.95-2.29); } \\
0.08^{\text {AA+TAvsTT }}\end{array}$ \\
\hline $\begin{array}{l}\text { ANA Ab (positive/negative) } \\
\text { OR ( } 95 \% \mathrm{Cl}) \\
\text { P-value }\end{array}$ & I.0 (reference) & $\begin{array}{l}0.45(0.015-1.30) \\
0.223^{\text {TAvsTT }}\end{array}$ & $\begin{array}{l}0.35(0.04-3.08) \\
0.340^{\text {AAvsTT }}\end{array}$ & $\begin{array}{l}0.43(0.15-1.23) \\
0.106^{\text {AA+TAvsTT }}\end{array}$ \\
\hline $\begin{array}{l}\text { Anti-dsDNA Ab (positive/negative) } \\
\text { OR ( } 95 \% \mathrm{Cl}) \\
\text { P-value }\end{array}$ & I.0 (reference) & $\begin{array}{l}2.59(1.55-4.35) \\
0.000^{\text {TAvsTT }}\end{array}$ & $\begin{array}{l}0.81(0.26-2.47) \\
0.707^{\text {AAvsTT }}\end{array}$ & $\begin{array}{l}2.24(1.38-3.62) \\
0.001^{\text {AA+TAvsTT }}\end{array}$ \\
\hline $\begin{array}{l}\text { Anti-Smith Ab (positive/negative) } \\
\text { OR ( } 95 \% \mathrm{Cl}) \\
\text { P-value }\end{array}$ & 1.0 (reference) & $\begin{array}{l}\text { I.63(0.98-2.7I); } \\
0.056^{\text {TAvsTT }}\end{array}$ & $\begin{array}{l}4.48(1.44-13.92) \\
0.014^{\text {AAvsTT }}\end{array}$ & $\begin{array}{l}\text { I.83(I.13-2.97); } \\
0.013^{\text {AA+TAvsTT }}\end{array}$ \\
\hline
\end{tabular}


Table 4 (Continued).

\begin{tabular}{|c|c|c|c|c|}
\hline \multirow[t]{2}{*}{ Parameter } & \multicolumn{4}{|c|}{ Genotype Distributions } \\
\hline & TT & TA & AA & TA+AA \\
\hline $\begin{array}{l}\text { Anti-Ro/SSA Ab (positive/negative) } \\
\text { OR }(95 \% \mathrm{Cl}) \\
\text { P-value }\end{array}$ & I.0 (reference) & $\begin{array}{l}\text { I.29(0.80-2.07); } \\
0.292^{\text {TAvsTT }}\end{array}$ & $\begin{array}{l}0.43(0.09-2.00) \\
0.432^{\text {AAvsTT }}\end{array}$ & $\begin{array}{l}\text { I.I8(0.74-I.87); } \\
0.485^{\text {AA+TAvsTT }}\end{array}$ \\
\hline $\begin{array}{l}\text { Anti-La/SSB Ab (positive/negative) } \\
\text { OR ( } 95 \% \mathrm{Cl}) \\
\text { P-value }\end{array}$ & I.0 (reference) & $\begin{array}{l}0.60(0.3 \mathrm{I}-\mathrm{I} .13) \\
0.112^{\text {TAvsTT }}\end{array}$ & $\begin{array}{l}0.36(0.04-2.80) \\
0.509^{\text {AAvsTT }}\end{array}$ & $\begin{array}{l}0.57(0.30-1.07) \\
0.076^{\text {AA+TAvsTT }}\end{array}$ \\
\hline $\begin{array}{l}\text { Anti-RNP Ab (positive/negative) } \\
\text { OR ( } 95 \% \mathrm{Cl}) \\
\text { P-value }\end{array}$ & I.0 (reference) & $\begin{array}{l}0.84(0.53-1.33) \\
0.465^{\text {TAvsTT }}\end{array}$ & $\begin{array}{l}\text { I.69(0.55-5.17); } \\
0.356^{\text {AAvsTT }}\end{array}$ & $\begin{array}{l}0.9 \mathrm{I}(0.59-\mathrm{I} .4 \mathrm{I}) \\
0.666^{\mathrm{AA}+\mathrm{TAvs} T \mathrm{~T}}\end{array}$ \\
\hline $\begin{array}{l}\text { SLEDAI } \\
{\text { Mild } / \text { stable }^{\mathrm{a}}} \\
\text { OR }(95 \% \mathrm{Cl}) \\
\text { P-value }\end{array}$ & I.0 (reference) & $\begin{array}{l}2.25(0.60-8.50) \\
0.222^{\text {TAvsTT }}\end{array}$ & $\begin{array}{l}0.75(0.07-7.77) \\
\text { I.000 AAvsTT }\end{array}$ & $\begin{array}{l}\text { I.88(0.57-6.20); } \\
0.298^{\text {AA+TAvs TT }}\end{array}$ \\
\hline $\begin{array}{l}\text { Moderate } / \text { stable }^{\mathrm{a}} \\
\text { OR }(95 \% \mathrm{Cl}) \\
\text { P-value }\end{array}$ & I.0 (reference) & $\begin{array}{l}2.06(0.56-7.52) \\
0.406^{\text {TAvsTT }}\end{array}$ & $\begin{array}{l}0.69(0.07-6.31) \\
0.553^{\text {AAvsTT }}\end{array}$ & $\begin{array}{l}\text { I.68(0.53-5.38); } \\
0.377^{\text {AA+TAvsTT }}\end{array}$ \\
\hline $\begin{array}{l}\text { Severe } / \text { stable }^{\mathrm{a}} \\
\text { OR }(95 \% \mathrm{Cl}) \\
\text { P-value }\end{array}$ & I.0 (reference) & $\begin{array}{l}\text { 2.43(0.66-8.95); } \\
0.172^{\text {TAvsTT }}\end{array}$ & $\begin{array}{l}0.75(0.08-7.19) \\
1.000^{\text {AAvsTT }}\end{array}$ & $\begin{array}{l}2.01(0.62-6.48) \\
0.237^{A A+T A v s T T}\end{array}$ \\
\hline $\begin{array}{l}\text { SDI (> } 0 \text { score/ = } 0 \text { scores) } \\
\text { OR ( } 95 \% \mathrm{Cl}) ; \\
\text { P-value }\end{array}$ & I.0 (reference) & $\begin{array}{l}\text { I.I2(0.12-I.75); } \\
0.615^{\text {TAvsTT }}\end{array}$ & $\begin{array}{l}4.15(1.12-15.45) \\
0.022^{\text {AAvsTT }}\end{array}$ & $\begin{array}{l}\text { I.27(0.82-I.94); } \\
0.282^{\text {AA+TAvsTT }}\end{array}$ \\
\hline
\end{tabular}

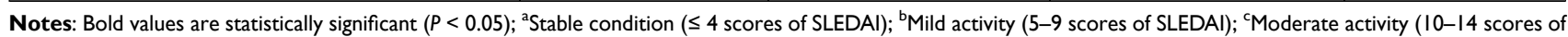
SLEDAI); 'Severe activity ( $\geq 15$ scores of SLEDAI).

Abbreviations: N, number; Ab, antibodies; dsDNA, double stranded DNA; RNP, ribonucleoprotein; ANA, anti-nuclear antibodies; SD, standard deviation. SDI, SLICC/ACR damage index scores.

needed to address these conflicting findings. The IFN- $\gamma$ +874 T/A polymorphism was shown to be related to IFN- $\gamma$ levels and, ${ }^{21}$ thus, we hypothesized that this polymorphism modifies the risk of SLE by altering IFN- $\gamma$ levels.

In reviewing reports from other counties, Hrycek et al from Poland first explore the link between the +874 T/A polymorphism of IFN- $\gamma$ gene and SLE risk, and found that this SNP was not connected to the risk of SLE. ${ }^{24}$ Subsequent two studies from Thailand also did not obtain an association between this SNP and SLE risk. ${ }^{23,25}$ However, Hirankarn et al observed that the combined effect of a SNP of the IL-18 gene and this polymorphism correlated with arthritis in SLE patients. ${ }^{25}$ In addition, an Iranian study did not find a link between the IFN- $\gamma+874$ T/A polymorphism and a risk of juvenile SLE. ${ }^{26}$ Kim et al indicated that this polymorphism was related to an increased risk of SLE in two-stage studies with large sample sizes. ${ }^{27,28} \mathrm{~A}$ Brazilian study replicated a positive association regarding this issue. ${ }^{22}$ To address these inconsistent results, Lee et al conducted a meta-analysis to interpret the relationship between the $+874 \mathrm{~T} / \mathrm{A}$ polymorphism and the risk of autoimmune disease, ${ }^{40}$ and found that this polymorphism elevated the risk of SLE. However, this meta-analysis only included two studies, ${ }^{22,23}$ and other relevant studies ${ }^{24-28}$ were not included. Thus, we should interpret these results with caution.

In this study, we detected that the $+874 \mathrm{~T} / \mathrm{A}$ polymorphism of the IFN- $\gamma$ gene elevated the risk of SLE in Chinese individuals, particularly among females. In addition, we interpreted the link between this polymorphism and clinical features of SLE patients. Data revealed that this polymorphism was related with lupus nephritis, proteinuria, antidsDNA Ab, anti-Sm Ab, and SDI. A study from Thailand found that this polymorphism was linked with arthritis 
manifestations in SLE patients, ${ }^{23}$ which was not shown in our study. However, the Brazilian study by da Silva et al did not find a link between this SNP and clinical manifestations of SLE. ${ }^{22}$ In addition, we analyzed the association between disease activity (SLEDAI) and damage indices (SDI) of SLE patients, and did not find that the disease activity had a correlation with damage indices (data not shown). SLEDAI indicated the immediate disease status, while SDI implied continuous cumulative disease damage. That may be a potential reason to explain why the disease activity did not show an association with damage indices. To summarize, whether the IFN- $\gamma+874$ T/A polymorphism correlated with some of the clinical features of SLE may be related to factors including race, various stages of SLE, or genetic or clinical heterogeneity.

In addition, we conducted a meta-analysis including the above-mentioned studies and this study. The meta-analysis suggested that this polymorphism increased the risk of SLE, which was in line with a previous meta-analysis. ${ }^{40}$ Subgroup analysis revealed that the IFN- $\gamma+874 \mathrm{~T} / \mathrm{A}$ polymorphism was linked to an elevated risk of SLE among Asians. Lee et al did not perform subgroup analysis by ethnicity, ${ }^{40}$ possibly due to the limited number of studies. Thus, further studies involving other ethnicities are urgently needed.

Advantages of our study included that this study is the first to find that the IFN $-\gamma+874 \mathrm{~T} / \mathrm{A}$ polymorphism is related with an elevated risk of SLE in a Chinese Han population. This study included moderate sample size with reliable results. In addition, the study detected that this polymorphism was connected to some clinical features of SLE, which was not shown in other studies. However, some limitations were shown in this study. One, only one SNP of the IFN- $\gamma$ gene was investigated. Two, this case-control study may have a selection bias, because it was hospital-based. Three, interactions between environmental and genetic factors should be explored. Finally, the biological functions of the polymorphism remain poorly understood.

Totally, the IFN- $\gamma+874$ T/A polymorphism shows a connection to the risk and clinical features of SLE in Chinese subjects. These results may help to identify some novel genetic factors for SLE patients.

\section{Funding}

The authors did not receive any funding.

\section{Disclosure}

The authors report no conflicts of interest in this work.

\section{References}

1. Fanouriakis A, Tziolos N, Bertsias G, Boumpas DT. Update omicron the diagnosis and management of systemic lupus erythematosus. Ann Rheum Dis. 2021;80(1):14-25. doi:10.1136/annrheumdis-2020218272

2. Kiriakidou M, Ching CL. Systemic lupus erythematosus. Ann Intern Med. 2020;172(11):ITC81-ITC96. doi:10.7326/AITC202006020

3. Tsokos GC. Autoimmunity and organ damage in systemic lupus erythematosus. Nat Immunol. 2020;21(6):605-614. doi:10.1038/ s41590-020-0677-6

4. Murphy G, Isenberg DA. New therapies for systemic lupus erythematosus - past imperfect, future tense. Nat Rev Rheumatol. 2019;15 (7):403-412. doi:10.1038/s41584-019-0235-5

5. Catalina MD, Owen KA, Labonte AC, Grammer AC, Lipsky PE. The pathogenesis of systemic lupus erythematosus: harnessing big data to understand the molecular basis of lupus. $J$ Autoimmun. 2020;110:102359. doi:10.1016/j.jaut.2019.102359

6. Fava A, Petri M. Systemic lupus erythematosus: diagnosis and clinical management. J Autoimmun. 2019;96:1-13. doi:10.1016/j. jaut.2018.11.001

7. Kaul A, Gordon C, Crow MK, et al. Systemic lupus erythematosus. Nat Rev Dis Primers. 2016;2:16039. doi:10.1038/nrdp.2016.39

8. Dorner T, Furie R. Novel paradigms in systemic lupus erythematosus. Lancet. 2019;393(10188):2344-2358. doi:10.1016/S0140-6736(19) 30546-X

9. Morris DL, Sheng Y, Zhang Y, et al. Genome-wide association meta-analysis in Chinese and European individuals identifies ten new loci associated with systemic lupus erythematosus. Nat Genet. 2016;48(8):940-946. doi:10.1038/ng.3603

10. Bentham J, Morris DL, Graham DSC, et al. Genetic association analyses implicate aberrant regulation of innate and adaptive immunity genes in the pathogenesis of systemic lupus erythematosus. Nat Genet. 2015;47(12):1457-1464. doi:10.1038/ng.3434

11. Coke LN, Wen H, Comeau M, et al. Arg206Cys substitution in DNASE1L3 causes a defect in DNASE1L3 protein secretion that confers risk of systemic lupus erythematosus. Ann Rheum Dis. 2021;80(6):782-787. doi:10.1136/annrheumdis-2020-218810

12. Yin X, Kim K, Suetsugu H, et al. Meta-analysis of 208370 East Asians identifies 113 susceptibility loci for systemic lupus erythematosus. Ann Rheum Dis. 2020. doi:10.1136/annrheumdis2020-219209

13. Wen L, Zhu C, Zhu Z, et al. Exome-wide association study identifies four novel loci for systemic lupus erythematosus in Han Chinese population. Ann Rheum Dis. 2018;77(3):417. doi:10.1136/annrheumdis-2017-211823

14. Psarras A, Emery P, Vital EM. Type I interferon-mediated autoimmune diseases: pathogenesis, diagnosis and targeted therapy. Rheumatology. 2017;56(10):1662-1675. doi:10.1093/rheumatology/ kew431

15. Ye L, Schnepf D, Staeheli P. Interferon- $\lambda$ orchestrates innate and adaptive mucosal immune responses. Nat Rev Immunol. 2019;19 (10):614-625. doi:10.1038/s41577-019-0182-z

16. Liu M, Liu J, Hao S, et al. Higher activation of the interferon-gamma signaling pathway in systemic lupus erythematosus patients with a high type I IFN score: relation to disease activity. Clin Rheumatol. 2018;37 (10):2675-2684. doi:10.1007/s10067-018-4138-7

17. Thomason JL, Obih UM, Koelle DM, Lood C, Hughes AG. An interferon-gamma release assay as a novel biomarker in systemic lupus erythematosus. Rheumatology. 2020;59(11):3479-3487. doi:10.1093/rheumatology/keaa161

18. Cesaroni M, Seridi L, Loza MJ, et al. Response to ustekinumab treatment in patients with systemic lupus erythematosus is linked to suppression of serum interferon gamma levels. Arthritis Rheumatol. 2020. doi:10.1002/art.41547 
19. Postal M, Ruocco HH, Brandao CO, et al. Interferon-gamma is associated with cerebral atrophy in systemic lupus erythematosus. Neuroimmunomodulation. 2017;24(2):100-105. doi:10.1159/ 000479319

20. Kokic V, Martinovic Kaliterna D, Radic M, Perkovic D, Cvek M, Capkun V. Relationship between vitamin D, IFN-gamma, and E2 levels in systemic lupus erythematosus. Lupus. 2016;25(3):282-288. doi:10.1177/0961203315605367

21. Izad M, Vodjgani M, Nicknam MH, Lotfi J, Fathi D, Amirzargar AA. Interferon-gamma gene polymorphism in Iranian patients with multiple sclerosis. Iran J Allergy Asthma Immunol. 2004;3(3):115-119.

22. da Silva HD, da Silva AP, da Silva HA, Asano NM, Maia Mde M, de Souza PR. Interferon gamma and Interleukin 10 polymorphisms in Brazilian patients with systemic lupus erythematosus. Mol Biol Rep. 2014;41(4):2493-2500. doi:10.1007/s11033-014-3106-9

23. Tangwattanachuleeporn M, Sodsai P, Avihingsanon Y, Wongpiyabovorn J, Wongchinsri J, Hirankarn N. Association of interferon-gamma gene polymorphism (+874A) with arthritis manifestation in SLE. Clin Rheumatol. 2007;26(11):1921-1924. doi:10.1007/s10067-007-0699-6

24. Hrycek A, Siekiera U, Cieslik P, Szkrobka W. HLA-DRB1 and DQB1 alleles and gene polymorphisms of selected cytokines in systemic lupus erythematosus. Rheumatol Int. 2005;26(1):1-6. doi: 10.1007/s00296-004-0503-8

25. Hirankarn N, Tangwattanachuleeporn M, Wongpiyabovorn J, Wongchinsri J, Avihingsanon Y. Association of IL-18 gene polymorphism (-137C) with arthritis manifestations in SLE: combined effect with IFN gamma gene polymorphism (+874A). Clin Rheumatol. 2009;28(2):219-223. doi:10.1007/s10067-008-1036-4

26. Harsini S, Ziaee V, Tahghighi F, et al. Association of interleukin-2 and interferon-gamma single nucleotide polymorphisms with Juvenile systemic lupus erythematosus. Allergol Immunopathol. 2016;44(5):422-426. doi:10.1016/j.aller.2015.12.005

27. Kim K, Cho SK, Sestak A, Namjou B, Kang C, Bae SC. Interferongamma gene polymorphisms associated with susceptibility to systemic lupus erythematosus. Ann Rheum Dis. 2010;69(6):1247-1250. doi:10.1136/ard.2009.117572

28. Kim K, Park SY, Kim T, et al. Replicated association of a regulatory polymorphism in the interferon gamma gene with lupus susceptibility. Ann Rheum Dis. 2011;70(10):1878-1879. doi:10.1136/ard.2010.147249

29. Gladman D, Ginzler E, Goldsmith C, et al. The development and initial validation of the Systemic Lupus International Collaborating Clinics/American College of Rheumatology damage index for systemic lupus erythematosus. Arthritis Rheum. 1996;39(3):363-369. doi:10.1002/art.1780390303
30. Qiu H, Xie Z, Tang W, et al. Association between microRNA-146a, -499a and -196a-2 SNPs and non-small cell lung cancer: a casecontrol study involving 2249 subjects. Biosci Rep. 2021;41:2. doi:10.1042/BSR20201158

31. Zheng L, Yin J, Wang L, et al. Interleukin 1B rs16944 G>A polymorphism was associated with a decreased risk of esophageal cancer in a Chinese population. Clin Biochem. 2013;46(15):1469-1473. doi:10.1016/j.clinbiochem.2013.05.050

32. Chun HY, Chung JW, Kim HA, et al. Cytokine IL-6 and IL-10 as biomarkers in systemic lupus erythematosus. J Clin Immunol. 2007;27(5):461-466. doi:10.1007/s10875-007-9104-0

33. Gomez D, Correa PA, Gomez LM, Cadena J, Molina JF, Anaya JM. Th1/Th2 cytokines in patients with systemic lupus erythematosus: is tumor necrosis factor alpha protective? Semin Arthritis Rheum. 2004;33(6):404 413. doi:10.1016/j.semarthrit.2003.11.002

34. Kim T, Kanayama Y, Negoro N, Okamura M, Takeda T, Inoue T. Serum levels of interferons in patients with systemic lupus erythematosus. Clin Exp Immunol. 1987;70(3):562-569.

35. Al-Janadi M, Al-Balla S, Al-Dalaan A, Raziuddin S. Cytokine profile in systemic lupus erythematosus, rheumatoid arthritis, and other rheumatic diseases. J Clin Immunol. 1993;13(1):58-67. doi:10.1007/BF00920636

36. Tokano Y, Morimoto S, Kaneko H, et al. Levels of IL-12 in the sera of patients with systemic lupus erythematosus (SLE)-relation to Th1and Th2-derived cytokines. Clin Exp Immunol. 1999;116(1):169-173. doi:10.1046/j.1365-2249.1999.00862.x

37. Robak E, Smolewski P, Wozniacka A, Sysa-Jedrzejowska A, Stepien H, Robak T. Relationship between peripheral blood dendritic cells and cytokines involved in the pathogenesis of systemic lupus erythematosus. Eur Cytokine Netw. 2004;15(3):222-230.

38. Viallard JF, Pellegrin JL, Ranchin V, et al. Th1 (IL-2, interferongamma (IFN- $\gamma$ )) and Th2 (IL-10, IL-4) cytokine production by peripheral blood mononuclear cells (PBMC) from patients with systemic lupus erythematosus (SLE). Clin Exp Immunol. 1999;115 (1):189-195. doi:10.1046/j.1365-2249.1999.00766.x

39. Lacki JK, Leszczynski P, Kelemen J, Muller W, Mackiewicz SH. Cytokine concentration in serum of lupus erythematosus patients: the effect on acute phase response. J Med. 1997;28(1-2):99-107.

40. Lee YH, Bae SC. Association between interferon-gamma +874 T/A polymorphism and susceptibility to autoimmune diseases: a meta-analysis. Lupus. 2016;25(7):710-718. doi:10.1177/ 0961203315624557
Pharmacogenomics and Personalized Medicine

\section{Publish your work in this journal}

Pharmacogenomics and Personalized Medicine is an international, peer-reviewed, open access journal characterizing the influence of genotype on pharmacology leading to the development of personalized treatment programs and individualized drug selection for improved safety, efficacy and sustainability. This journal is indexed on the American Chemical Society's Chemical Abstracts Service (CAS). The manuscript management system is completely online and includes a very quick and fair peer-review system, which is all easy to use. Visit http://www.dovepress.com/testimonials.php to read real quotes from published authors. 